ARTIGO

\title{
O CIVISMO NO ENSINO DE HISTÓRIA EM TEMPOS AUTORITÁRIOS NO ESPÍRITO SANTO (1937-1945 E 1964-1985)
}

\author{
MIRIÃ LÚCIA LUIZ ${ }^{1}$ \\ ORCID: http://orcid.org/0000-0001-6825-1541 \\ PAULA FLORINDA DE FREITAS FARIA ${ }^{2}$ \\ ORCID: http://orcid.org/0000-0002-0895-3063
}

\begin{abstract}
RESUMO: Analisa contornos atribuídos ao civismo no ensino de História no Espírito Santo durante a ditadura do Estado Novo (1937-1945) e o regime civil-militar (1964-1985). As fontes analisadas compreendem o conjunto de documentos produzidos e/ou que circularam em escolas públicas capixabas. Parte do pensamento de Bloch (2001) e Ginzburg $(2002,2007)$ para a interrogação das fontes. Das expectativas oficializadas nas prescrições observa-se, por um lado, a intervenção do Estado no que se refere ao ensino de História nas escolas e, por outro, a ênfase ao civismo e patriotismo materializados nesses documentos. Porém, no caso específico das escolas capixabas, há indícios de práticas distintas do prescrito para o Ensino de História, como as críticas dos professores às propostas curriculares, a defesa por um ensino de História reflexivo e instigante, além dos concursos de bolo e aulas de corte e costura, que revelam modos plurais de se pensar e ensinar História em tempos autoritários.
\end{abstract}

Palavras-chave: Civismo, Ensino de História, Estado Novo, Ditadura Civil-militar.

\section{CIVILITY IN TEACHING HISTORY IN AUTHORITARIAN TIMES IN ESPÍRITO SANTO (1937-1945 AND 1964-1985)}

\begin{abstract}
This paper analyzes contours attributed to civility in the teaching of History in Espírito Santo State during the Estado Novo dictatorship (1937-1945) and the civil-military regime (1964-1985). The sources analyzed comprise the set of documents produced and/or circulated in public schools in the state of Espírito Santo. It is based on the thinking of Bloch (2001) and Ginzburg $(2002,2007)$ for the interrogation of sources. From the official expectations of the prescriptions, one observes, on the one hand, the intervention of the State on History teaching in schools and, on the other hand, the emphasis on civility and patriotism materialized in these documents. However, in the specific case of the schools in the state of Espirito Santo, there are indications of practices that differ from those prescribed for History Teaching, such as the criticism of teachers towards curricular proposals, the defense of a

\footnotetext{
1 Departamento de Educação, Política e Sociedade da Universidade Federal do Espírito Santo (UFES). Vitória, ES, Brasil. $<$ mirialuiz@gmail.com>

${ }^{2}$ Secretaria de Estado da Educação do Espírito Santo. Vitória, ES, Brasil. <paulafff@gmail.com> 
thoughtful and instigating History teaching, besides the cake contests and cutting and sewing classes, which reveal plural ways of thinking and teaching History in authoritarian times.

Keywords: Civility, History Teaching, Estado Novo, Civil-Military Dictatorship.

\section{EL CIVISMO PARA LA ENSEÑANZA DE LA HISTORIA EN TIEMPOS AUTORITARIOS EN ESPÍRITO SANTO (1937-1945 E 1964-1985)}

RESÚMEN: Este artículo analiza los límites atribuidos al civismo para la enseñanza de la Historia en el estado de Espirito Santo, durante la dictadura del Estado Nuevo (1937-1945) y del régimen civil-militar (1964-1985). Las fuentes analizadas comprenden un conjunto de documentos producidos y/o que circularon en las escuelas públicas capixabas. En el análisis de las fuentes contribuyeron los pensamientos de Bloch (2001) y Ginzburg (2002, 2007). En las normativas oficiales, se observan dos aspectos: por un lado, la intervención del Estado en lo que se refiere a la enseñanza de la Historia en las escuelas, y por otro, el énfasis del civismo y el patriotismo materializados en estos documentos. Sin embargo, en el caso específico de las escuelas capixabas, hay indicios de prácticas diferentes de lo establecido para la enseñanza de la Historia, como las críticas de los maestros a las propuestas curriculares, la defensa de una enseñanza reflexiva y motivante de la historia, además de los concursos de pastelería y las clases de corte y costura, que revelan formas plurales de pensar y enseñar Historia en tiempos autoritarios.

Palabras clave: Civismo, Enseñanza de la Historia, Estado Nuevo, Dictadura Civil-militar. 


\section{INTRODUÇÃO}

"Houve um tempo em que o ensino da história nas escolas não era mais do que uma forma de educação cívica" (LAVILLE, 1999, p. 126). Com essa afirmação, Laville iniciou uma reflexão em torno das narrativas históricas contempladas em propostas curriculares de vários países e das disputas em torno desse ensino. Para o autor, essa educação de caráter cívico voltava-se para confirmar a ordem social e política tanto da nação quanto dos seus dirigentes e, ao mesmo tempo, inculcar em seus membros - vistos, então, mais como súditos do que como cidadãos participantes - o respeito, a dedicação e o orgulho de a ela pertencerem e servi-la. Esse objetivo, de acordo com o autor, vai se tornando menos necessário a partir do momento em que as nações se perceberam bem assentadas e cessaram de temer por sua própria existência.

Após a Segunda Guerra Mundial, com a vitória da democracia, a ideia de cidadão participante começou a substituir a de cidadão-súdito. Para o ensino de História, isso representou a substituição da instrução nacional pela educação para a cidadania democrática (LAVILLE, 1999).

No Brasil, a construção do ideário cívico remonta ao período pós-independência, com movimentos organizados como a Liga da Defesa Nacional, fundada por Olavo Bilac, em 1915, que já expressavam sua presença no pensamento social brasileiro (MAIA, 2013). A luta por uma pátria brasileira, em distinção e oposição a Portugal, e de uma cidadania brasileira independente da metrópole são compreendidas por Gomes (2009b) como um momento original do processo de construção de um Estado nacional e de um certo desenho de direitos. Porém, é com o discurso republicano que se busca estabelecer sólidos vínculos entre a República e a criação de uma cultura cívico-patriótica, capaz de produzir novos cidadãos.

Ao focalizarmos os contornos do ideário cívico no Brasil, buscamos em José Murilo de Carvalho, na obra Pontos e bordados: escritos de História e Política (1999), pistas de como se deu a construção da cidadania no Brasil. Para tanto, o autor discute o estudo histórico de Marshall sobre a evolução dos direitos que compõem a cidadania: civis, políticos e sociais. No caso inglês, investigado por Marshall, esses direitos surgiram sequencialmente. Em primeiro lugar, vieram os direitos civis; com base na posse desses direitos, foram reivindicados os direitos políticos. Finalmente, conquistados os direitos políticos, e graças a eles conseguida a participação no poder, foram implantados os direitos sociais. Essa sequência, no entanto, não é um modelo rígido. No caso brasileiro, ocorreu uma espécie de superposição de demandas por direitos, especialmente após a proclamação da República, o que deu ao processo de construção da cidadania grande complexidade. Gomes (2009) assinala o pós-30, assim como o pós-64, como períodos em que os direitos sociais mais avançaram no Brasil e, em ambos os momentos, o exercício dos direitos políticos e civis foram parcialmente ou totalmente suprimidos, sendo os últimos os alvos mais frequentes dos regimes políticos autoritários.

Nas palavras de Gomes, há uma "convergência quanto à imperiosa necessidade política da República de produzir um novo discurso político, carregado de valores e simbologias cívico-morais, no qual a história pátria, ao lado da geografia, tinha um lugar fundamental” (GOMES, 2009a, p. 1).

Ao longo da constituição da disciplina de História, observamos a permanência desse ideário, que assume diferentes feições, a julgar pelos interesses do Estado com o projeto de país que se deseja construir. Expressões como "Ensinar História para a formação cívica", "A História voltada para o fortalecimento dos sentimentos de civismo, os direitos e deveres das novas gerações para com a pátria e a humanidade" e "o preparo do cidadão para o exercício das atividades cívicas com fundamento na moral, no patriotismo e na ação da obediência à lei, da fidelidade ao trabalho e da integração na comunidade" ${ }^{3}$ são expressões que povoam programas e currículos produzidos para o ensino de História durante toda a sua trajetória como disciplina no país. ${ }^{4}$ Não obstante, temos nos deparado com alocuções de cunho

\footnotetext{
${ }^{3}$ Ver Fonseca (2003); Bittencourt (2004).

${ }^{4}$ Schmidt (2012) periodiza da seguinte forma a História do Ensino de História: 1838 a 1931: Criação do código disciplinar História; 1931 a 1971: Consolidação da disciplina; 1971 a 1984: Crise no código disciplinar e 1984 até a atualidade: Reconstrução da disciplina.
} 
similar, sobretudo, em pronunciamentos oficiais do governo federal e de defensores desse modo de pensar a História e seu ensino.

No principiar desse século, Bittencourt parecia acreditar que a permanência da História nos currículos das escolas de educação básica parecia estar assegurada, tendo em vista as inúmeras propostas curriculares produzidas e publicadas a partir da década de 1980 pelas secretarias estaduais de educação e pelo Ministério da Educação. No entanto, com a Reforma do Ensino Médio (Lei 13.415/2017) e com a Base Nacional Curricular Comum (BNCC, 2017), ${ }^{5}$ essa permanência, no que se refere ao Ensino Médio, encontra-se ameaçada. O currículo do Ensino Médio constitui-se atualmente por treze disciplinas obrigatórias. Com as mudanças propostas pela nova BNCC, 60\% da carga horária do aluno deverá obedecer ao estipulado pela base curricular. Os outros $40 \%$ se tornarão optativos, para os alunos ou para a escola. ${ }^{6}$ A partir dessa proposta, a disciplina de História integraria a parte optativa do currículo (BORGES; SALIM, 2017). Isso nos permite interrogar: o que estaria fundamentando a defesa por uma educação cívica e, ao mesmo tempo, pela exclusão da História do repertório curricular?

Partimos, portanto, para essa reflexão, da compreensão de Bloch (2001), de que o tempo presente é o ponto de partida do processo de investigação histórica. É com o olhar para discursos atuais que tomam como mote a educação cívica, essa "última película intacta do filme", que buscamos reconstituir os vestígios quebrados das outras. Para tanto, temos obrigação de, antes, desenrolar a bobina no sentido inverso das sequências.

Com a prática historiográfica pautada no pensamento de Bloch (2001) e Carlo Ginzburg (2002, 2007), interrogamos as fontes, buscando perseguir os indícios e as pistas que nos dizem dos contornos atribuídos ao civismo no ensino de História em escolas capixabas. Assim, pelo cruzamento do corpus documental, composto por manuais didáticos, propostas curriculares, provas de estudantes, relatórios de Estágios de Treinamentos em Recursos Audiovisuais, pontos de prova, publicações da imprensa periódica local, correspondências oficiais, registros e narrativas docentes, lemos o que os documentos revelam em sua face visível, bem como o que se abriga em suas "dobras" (GINZBURG, 2002).

Nesse caminho investigativo, o artigo busca compreender os sentidos atribuídos ao civismo no ensino de História durante dois períodos ditatoriais da História nacional: a Ditadura do Estado Novo $(1937-1945)^{7}$ e o regime civil-militar (1964-1985) ${ }^{8}$. Especificamente, analisamos documentos relativos à História ensinada, produzidos e/ou veiculados em escolas públicas capixabas durante esses dois períodos caracterizados pelo autoritarismo.

\section{A história prescrita e ensinada durante a ditadura do estado novo (1937-1945)}

No decorrer da pesquisa de mestrado que analisou o ensino de História no Ginásio do Espírito Santo (GES) durante o Estado Novo, destacamos a preponderância do civismo como elemento constituinte dos conteúdos da disciplina. O destaque do tema disparou reflexões acerca dos modos como

\footnotetext{
${ }^{5}$ A versão preliminar da Base Nacional Curricular Comum, lançada no dia 16 de setembro do ano de 2015, passou por consulta popular on-line. Depois de acirradas discussões entre especialistas, professores e entidades não governamentais, além de mudanças no quadro dos elaboradores e colaboradores documento, teve sua versão final homologada em 2018. Sobre o processo de elaboração da BNCC).

${ }^{6}$ A opção se dará entre cinco áreas de ênfase: Linguagens, Ciências da Natureza, Ciências Humanas, Matemática e Formação técnica e profissional.

${ }^{7}$ O Estado Novo teve início em 1937, quando Getúlio Vargas instituiu um governo de exceção com apoio dos militares. Foi centralizador, ao concentrar no nível federal a tomada de decisões antes partilhadas com os estados, e foi autoritário, centralizando no Executivo as atribuições anteriormente divididas com o Legislativo (OLIVEIRA; VELLOSO; GOMES, 1982).

${ }^{8}$ Regime político que tem início com o golpe de Estado de 1964 depõe o presidente João Goulart - segundo Fico (2014), ainda não anunciava a implantação de um regime ditatorial - e põe fim à "democracia populista" iniciada em 1946. De acordo com Germano (2011), apesar da iniciativa e do caráter burguês que se apresentavam, coube às Forças Armadas a intervenção executiva do golpe, mediante o qual assumiram o poder do Estado durante 21 anos.

${ }^{9}$ Este tópico parte dos resultados da Dissertação de Mestrado intitulada O ensino de História no Ginásio do Espírito Santo durante o Estado Novo (1937-1945), defendida no Programa de Pós-Graduação em Educação na Universidade Federal do Espírito Santo em 2019.
} 
o civismo é pensado e difundido em períodos de exceção caracterizados pelo autoritarismo. Ao tratarmos especificamente dos modos como o discurso cívico se expressa no ensino de História durante o Estado Novo em escolas capixabas, interrogamos o conjunto de fontes constituídas: pelas obras História do Brasil (1942) e Nossa Pátria (1917), ambas do autor Rocha Pombo; atividades escolares realizadas em escolas capixabas no período (1938; 1940); correspondências oficiais (1937); publicação do jornal Diário da Manhã (1937) e relatório da Secretaria da Educação e Saúde (1938).

Os manuais de História de Rocha Pombo ${ }^{10}$ coincidem com o período de consolidação da República brasileira, momento em que a História do Brasil almejava um novo significado. A necessidade de construir uma história sob o signo do progresso direcionou os livros didáticos a assumirem uma missão patriótica e cívica, possibilitando unidade a um país marcado pelos contrastes e que buscava um passado comum a todos os brasileiros, para despertar o sentimento de patriotismo e devoção à pátria. Coube ao ensino de História, portanto, a tarefa de difundir os ideais cívicos que atendiam a esse espírito republicano (OLIVEIRA, 2015; TORRES, 2012).

Nesse contexto, o livro Nossa Pátria, de Rocha Pombo, publicado pela primeira vez no ano de 1917, ainda compunha a listagem do acervo do Ginásio do Espírito Santo ${ }^{11}$ no ano de 1942. Sua presença entre as obras adotadas pela instituição tanto tempo após seu lançamento indica que, na década de 1940, o projeto de construção da identidade nacional unificada ainda não havia sido concluído (FARIA, 2019).

A ilustração na capa da obra (Imagem 1) chamou-nos a atenção especialmente porque há duas crianças que seguram a bandeira do Brasil, a qual é beijada por uma delas. Duas crianças segurando um dos principais símbolos nacionais e um beijo nesse símbolo são bastante representativos do civismo que permeia o conteúdo da obra.

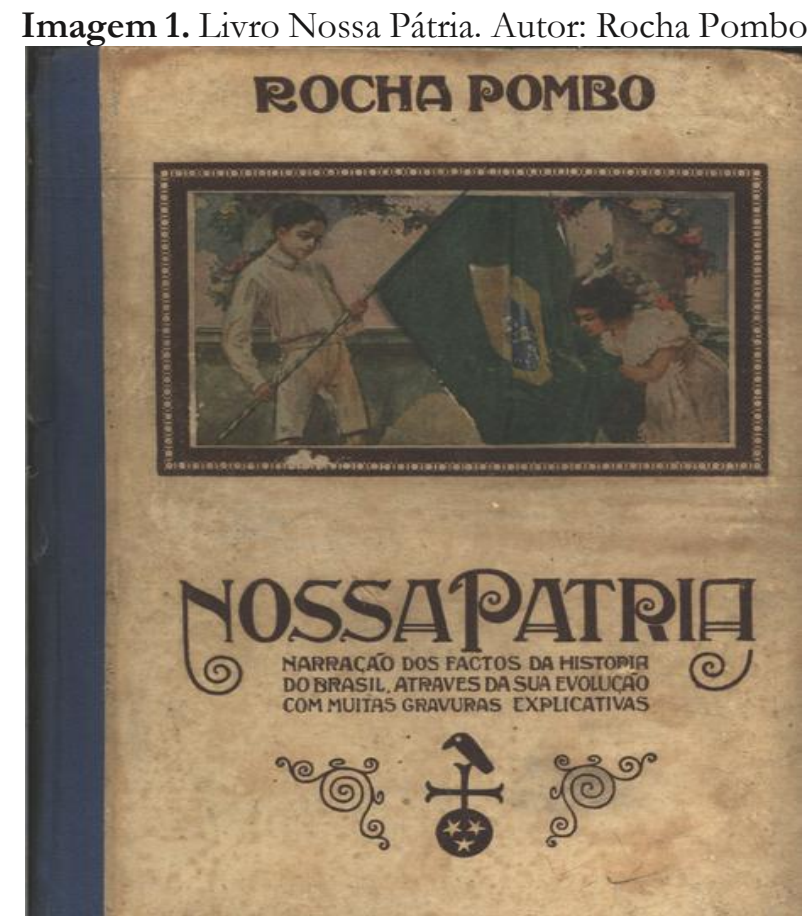

Fonte: Acervo pessoal (2019)

\footnotetext{
10 Professor do Colégio Pedro II, era representante da elite brasileira e buscava vincular em suas obras os ideais propostos pelo IGBH. Estes fatores contribuíram para a legitimação, aceitação e difusão de suas produções didáticas. Ser membro do IGBH concedia ao autor credibilidade e justifica a grande aceitação de suas obras nas escolas brasileiras (OLIVEIRA, 2015). 11 O GES, fundado em 1906, representava uma tentativa de estimular o ensino secundário, fragilizado pela descontinuidade das políticas públicas para educação em âmbito nacional. Nesse cenário, a adoção do modelo para o ensino secundário emanado do Colégio Pedro II, tinha por objetivo a integração do GES no projeto de unificação e consolidação da nação brasileira. Esse projeto atravessou o império estendendo-se durante o período republicano incluindo o Estado Novo (SIMÕES; SALIM; TAVARES, 2006, p. 5565). 
Ao longo da apresentação do livro, o autor afirma: "este livrinho é feito para a intelligencia das creanças e dos homens simples do povo (sic)" (POMBO, 1917, p. 3). O culto à pátria e o esforço em fazê-la ser conhecida e amada como elemento formador da existência moral são defendidos pelo autor na sequência do texto. $\mathrm{Na}$ conclusão, Pombo expressa o objetivo de buscar "[...] com todo carinho do seu coração fixar na alma das gerações os lances dos quais podemos nos orgulhar" (POMBO, 1917, p. 3). O público a quem Pombo destina seus escritos e o teor cívico deles coincidem com o projeto educacional estadonovista. ${ }^{12}$

A primeira unidade do livro de Rocha Pombo leva o nome do próprio livro e estampa a mesma foto da capa. Nessa unidade, o autor descreve o que entende por "Nossa Pátria":

Pátria! - Terra de nossos pais; onde viveram nossos avós; onde temos todas as recordações de nossa vida e da nossa família; onde tudo nos fala à alma - onde parece que até as estrelas e os próprios ares nos alegram mais que os outros céus!

É por isso que amamos nossa Pátria mais que as outras pátrias.

Nella estamos confiantes como o marujo na enseada conhecida, longe do mar alto e das tormentas. Ella é para nós como nossa própria Mái, pois nos abre o seio e nos protege, como se fossi uma continuação dos nossos lares. (Ibidem, p. 5)

Esse fragmento carrega em si todo o espírito do civismo veiculado na obra didática. Comporta a noção de pertencimento a uma nação, de fidelidade a uma pátria, de unidade, de passado em comum, de memória construída coletivamente, de cidadania, de ufanismo e da construção histórica.

A segunda unidade é dedicada à bandeira de Nossa Pátria em uma clara valorização dos símbolos nacionais republicanos. Além da bandeira, Pombo faz uma exaltação ao Hino da Pátria afirmando ser este o símbolo que sentimos pela audição. Nessa página, consta uma ilustração do Maestro Francisco Manoel com a indicação de ser ele o compositor do hino nacional. Para Rocha Pombo, o surgimento destes símbolos se mistura com a criação da nação brasileira. Diante da importância desses signos, o autor propõe que "deante da nossa bandeira, ouvindo a música da Pátria, ficamos em atitude de culto, descobertos como deante de um altar, e sempre ufanos de ver o sagrado pendão cada vez mais alto entre os das outras nações" (sic) (Ibidem, p. 8).

A exaltação da bandeira e do hino nacionais como símbolos republicanos não se restringia aos livros didáticos da época. O civismo descrito e pregado por Pombo permeava as atividades realizadas por professores e alunos de instituições capixabas.

O planejamento de aula do grupo escolar "Coronel Antônio Duarte" no ano de 1938 na cidade de Iconha - ES tem como tema "A Bandeira do Brasil". A lição solicitava ao aluno "falar sobre a primeira ideia da composição da Bandeira Republicana de acordo com o decreto número 4 de 19 de novembro de 1889". A orientação segue: "Falar sobre as cinco bandeiras que representam as cinco fases que o nosso país atravessou". Na descrição da atividade, constava: "Os alunos farão o relatório da aula dada, com o desenho da Bandeira do Brasil em uso" (GRUPO ESCOLAR CORONEL ANTÔNIO DUARTE, 1938).

Ainda no ano de 1938, um relatório do Grupo Escolar "Coronel Xavier"13", enviado ao secretário de educação Fernando Duarte Rabelo no dia 22 de novembro, fornece-nos pistas de uma solenidade permeada por rituais e símbolos cívico-patrióticos. O documento descreve o encerramento dos trabalhos escolares no educandário de acordo com as instruções da Secretaria de Educação e Saúde. A primeira parte da solenidade de conclusão do ano letivo intitulou-se "Comemoração à Bandeira" e teve início com a execução do Hino Nacional, seguida pela recepção à bandeira e pela execução do hino "Deixa beijar-te Bandeira" (GRUPO ESCOLAR CORONEL XAVIER, 1938). Após os hinos, procedeu-se a preleção sobre as fases da bandeira pela professora, e uma aluna responsabilizou-se pela oração à bandeira. No encerramento do evento, o Hino Nacional foi tocado pela segunda vez.

\footnotetext{
${ }^{12}$ Com a implantação do Estado Novo, a competência de estabelecer as bases e determinar os quadros da educação nacional, traçando as diretrizes da formação física, intelectual e moral da infância e da juventude, passa a ser do Estado (NUNES, 2001). 13 Antigo munícipio Sabino Pessoa, atual município de Jerônimo Monteiro. 
As fontes indiciam não somente a exaltação dos símbolos pátrios para a construção da narrativa cívica centrada no espírito republicano, pois se acrescenta a isso a seleção de episódios históricos, dentre eles, Rocha Pombo descreve a independência como o fato mais notável de nossa história, sendo por isso motivo de grande regozijo no coração de todos os brasileiros. Além da proposição de Rocha Pombo acerca da Independência do Brasil, um telegrama enviado pelo General Francisco José Pinto, secretário geral de educação, ao governador do Espírito Santo, João Punaro Bley, em 1937, trata de orientações relacionadas às comemorações cívicas da semana da Pátria. A correspondência determina que com a aproximação da "magna" data de aniversário da "nossa independência política" todos os municípios do estado celebrem com "veemente entusiasmo" o "Dia da Pátria" e a "Semana do Brasil" com festejos e solenidades incumbidos da

mesma fé patriótica na cruzada benemérita de exaltar nos corações patrícios os sentimentos de nacionalidade cultuando as tradições de civismo da nossa gente glorificando os heroes e os lances epicos do passado educando as gerações presentes para o labor fecundo e construtivo da grandeza do nosso futuro no continente com esses elevados propósitos sejam em todo território nacional as comemorações. (PINTO, 1937, n.p.)

A glorificação de "heróis" e de "lances épicos" constante no telegrama também está presente na obra de Rocha Pombo. Os dois primeiros capítulos de seu livro História do Brasil demonstram a intenção do autor em construir uma genealogia para História Brasileira. Das oito unidades que iniciam a obra, três recebem nomes próprios: Cristóvão Colombo, Vasco da Gama e Pedro Álvares Cabral sinalizando a utilização de feitos individuais de personalidades consideradas heroicas para a construção da narrativa cívica da história, característica marcante do período. Esse modelo historiográfico, a partir da criação de heróis como exemplo para os políticos, era amplamente utilizado pelo Instituto Histórico e Geográfico Brasileiro (IHGB) de quem Pombo era signatário (OLIVEIRA, 2015).

Pombo se insere entre os intelectuais do IHGB que buscavam construir um sentimento de unidade e pertencimento à nação brasileira atendendo aos interesses do Estado no período. É perceptível o interesse do autor em construir uma identidade nacional que contemplasse uma população tão heterogênea quanto à brasileira. Seus esforços buscavam possibilitar a essa população o acesso a um passado comum. O mesmo intuito que move o autor pode ser percebido na correspondência oficial do governo que objetivava unificar as solenidades em torno das comemorações da Independência em todo território brasileiro a partir das secretarias estaduais de educação.

O culto ao passado e a utilização da educação para a construção do ideário de nação estão presentes nas obras de Rocha Pombo. Além disso, na concepção histórica do autor, a explicação do passado pelo presente seria uma maneira de explicar o futuro pelo presente, constituindo, assim, as leis da história. Portanto, deduz-se que

se a política e moral de uma época é que iriam regular a moral e política da época subseqüente, para sabermos o que é ou o que vai ser a época subseqüente só será preciso conhecer a moral e a política da época de que a segunda tem de ser uma projeção. (POMBO, 1942, p. 52)

Assim como o autor, o telegrama oficial do governo e as atividades cívicas realizadas nas escolas capixabas também relacionam a construção do passado com a do futuro.

Rocha Pombo opta, em História do Brasil, por uma extensa análise descritiva da terra e pela busca de determinações geográficas que informam a compreensão de nação a se consolidar. Indicativo disso é a omissão das hostilidades entre portugueses, negros e indígenas ao descrever detalhadamente costumes, religião e comportamento de cada grupo étnico, sempre enaltecendo a "concórdia" entre as raças.

O detalhamento minucioso das características naturais do Brasil e a exposição de toda exuberância e riqueza natural brasileiras são utilizados por Pombo para enaltecer a superação dos colonizadores e sua interação com o babitat brasileiro, julgando ser necessária essa descrição porque corrobora a propaganda da terra e consequentemente fundamenta "toda a construção a levantar". Em 
suas palavras: "É nessa propaganda da terra e no nosso culto ao passado que há de se assentar a nossa educação" (Ibidem, p. 52).

Rocha Pombo dedica um capítulo de História do Brasil, ao que chama de Formação do Espírito Nacional, em que narra diversos episódios do século XVII, considerado por ele o "mais notável século de toda nossa história colonial". Ao longo das 13 unidades da obra, são enfatizadas principalmente as tentativas de invasão do território brasileiro e a resistência a essas investidas. É como se resistir às diversas incursões de estrangeiros fosse fundamental para a construção do "nosso espírito nacional".

Já em Nossa Pátria, Pombo se dedica à descrição dos elementos tidos como constituintes do povo brasileiro: os índios, os africanos e os europeus. O final do capítulo sobre os colonizadores é o único momento em que o autor aborda a miscigenação (sem utilizar a palavra mestiço ou mestiçagem) para tratar as características físicas ou o possível branqueamento da população do Brasil. O recurso utilizado foi a apresentação do brasileiro como herdeiro dos aspectos morais e psicológicos dos três grupos:

Vê-se, portanto, que a população do Brasil se formou dessas tres raças que temos indicado: os indios, que já estavam aqui; os africanos, que vieram como escravos; e os europeus, que tomaram conta do paiz. Por isso, o brasileiro tem as qualidades mais notaveis dessas tres raças: - é altivo, amoroso e inteligente (sic). (POMBO, 1917, p. 35)

Dessa maneira, Rocha Pombo, ao definir os formadores do Brasil e seus papéis na sociedade, atribui aos índios a altivez, aos negros a amabilidade e aos europeus a inteligência, sendo que a esses últimos coube a função de maior importância e prestígio: "tomar conta do paiz" (sic) (POMBO, 1917).

Avaliações aplicadas em escolas capixabas durante o Estado Novo indicam o alinhamento com o pensamento de Rocha Pombo expresso em seus livros. A prova realizada pela aluna Joana (11 anos), no dia 14 de novembro de 1940, na escola estadual Santa Rosa, tem como título "Prova de História Pátria" e subtítulo "Os indígenas". O texto aponta os indígenas como primeiros habitantes do Brasil e faz detalhada descrição de suas características físicas. Os indígenas são divididos entre tapuias e tupis. Os tapuias são descritos como "atrazados e bárbaros" enquanto os tupis "eram mais ou menos civilizados". O documento é constituído de detalhada descrição dos hábitos e costumes dos indígenas e se encerra afirmando que "os índios apesar de grosseiros, eram inteligentes" (ESCOLA SANTA ROSA, 1940). A escolha da descrição dos indígenas como tema de uma prova de História Pátria aponta para a utilização dos nativos como elementos formadores do espírito nacional que se buscava construir no momento.

Tanto no livro Nossa Pátria quanto no livro História do Brasil, Rocha Pombo exalta a atuação dos jesuítas e da Igreja Católica no Brasil. Seis unidades da obra História do Brasil referem-se à ação da Igreja Católica e dos padres jesuítas. Entre elas, a unidade intitulada "As grandes figuras de Nóbrega e Anchieta" enaltece a ação dos religiosos em seu trabalho de catequização dos indígenas.

É realmente admirável aquela indefectível grandeza moral com que uns quantos homens, em certos momentos de aflições para a consciência do mundo, tomam a si, com tanta paixão, a causa mais alta, mais legitimamente humana da história moderna. E o que mais impressiona hoje, tratando-se daqueles tempos, não é propriamente a dedicação sem limites do Jesuíta ao encontrar-se com as misérias e desgraças da família indígena: o que mais impressiona e espanta é ver como se igualavam e se uniam aqueles homens, com tal espontaneidade, com espirito tão íntegro e tão perfeito, que se diria todos uma única alma e a mesma índole. (POMBO, 1942, p. 178)

Já no livro Nossa Pátria, uma unidade é destinada à ação dos jesuítas. Sentimento de pátria é o título da $33^{\mathrm{a}}$ unidade que é antecedida por Como a terra foi cobiçada por extrangeiros; Tentativas de franceses e Tentativas de holandeses. Obviamente, essa disposição dos conteúdos demonstra o interesse do autor em valorizar as terras brasileiras muito cobiçadas por outros países, o que enaltece a primazia dos portugueses na ocupação do Brasil. A defesa do território brasileiro é utilizada como um componente formador do sentimento nacional patriótico.

Numa narrativa que se esforça por ignorar as relações de poder, força e dominação que permearam o processo de catequização, Pombo romantiza a presença dos religiosos até mesmo na opção 
pela grafia da palavra "jesuíta” com inicial maiúscula. Paixão, integridade e perfeição são recursos utilizados pelo autor para descrever a índole dos padres diante da miséria que a organização das famílias indígenas representava.

A atuação dos jesuítas também é tema de destaque nas atividades escolares do período. $\mathrm{Na}$ avaliação de História do Brasil realizada no dia 25 de novembro de 1940 na escola D. Maria Matos no município de Anchieta - ES, uma das questões é destinada à descrição de personalidades consideradas importantes para a história nacional. No enunciado, interroga-se: "Que parte tem na história nacional os nomes Anchieta, Caxias, Barão de Rio Branco, Duarte da Costa e Getúlio Vargas?”. Na resposta, o aluno descreve o jesuíta Padre José de Anchieta como "o grande catequista dos índios" (ESCOLA DONA MARIA MATOS, 1940).

Já na lista de pontos organizados para a segunda prova parcial de História do Brasil aplicada em 1940 no Ginásio do Espírito Santo, um tópico é destinado apenas à atuação da Companhia de Jesus no Brasil (GINÁSIO DO ESPÍRITO SANTO, 1940).

A valorização da atuação dos jesuítas presente nos livros de Rocha Pombo e nas avaliações escolares de escolas capixabas durante o Estado Novo demonstra a heroicização de personalidades históricas escolhidas para compor o passado comum que se pretendia construir. A romantização da participação da Igreja Católica na construção da nação brasileira objetivava embelezar a história assentada na comoção que pudesse causar, auxiliando no fortalecimento do patriotismo cívico.

Na última página de Nossa Pátria, Rocha Pombo retoma o incentivo ao desenvolvimento do sentimento patriótico e cívico com que começou a obra: "muito grato aos nossos corações é sentir como é bella a nossa historia; como tem lances que nos commovem, e que mostram quanto é nobre a funcção que, com o concurso de outras tantas, a nossa raça vai ter na America”. (sic) (POMBO, 1917, p. 154).

A escolha das imagens dos livros de Rocha Pombo indica a predileção do autor por personalidades que considerava importantes e de eventos de grande magnitude na clara tentativa de constituir um quadro de heróis atendendo às demandas das políticas educacionais estadonovistas que almejavam a construção de uma história da pátria que fosse nacionalista, ufanista e que estimulasse nos alunos esses mesmos sentimentos, constituindo uma História por meio dos exemplos.

Pelo exposto, concluímos que Rocha Pombo optou por uma historiografia que não se limitava ao simples registro dos fatos ou à mera descrição dos acontecimentos de uma sociedade. Ele buscava compreender o sentido das ações coletivas e as relações entre os fatos humanos, sempre direcionando sua narrativa à formação de um espírito que contemplasse todos os brasileiros e os remetesse ao sentimento de pertencimento a uma nação forte, unificada, de quem ama sua pátria e que se utiliza da sua história para o exercício da cidadania. Participar da vida política do Brasil, na concepção de Pombo, incluía conhecer os fatos de sua História e valorizá-los, utilizando-se do civismo para isso.

A comparação do conteúdo dos livros de Rocha Pombo com os conteúdos constantes nos programas da disciplina de História das décadas de 1930 e 1940 aponta mais para similitudes do que para discordâncias. O projeto de nação imaginado por Pombo em 1917 não tinha sido concluído durante Estado Novo, e o civismo, juntamente com o ufanismo, ainda eram os temas direcionadores da historiografia e do ensino de História no Brasil. Por isso, Pombo se situa entre inúmeros autores de livros para o ensino primário e secundário que, desde o início do século XX, apostavam na eficácia do ensino de História na conformação de um cidadão adaptado à ordem social e política em vigor. O autor afirmava ser necessário desenvolver nos jovens "o gosto pela história" como condição para a criação de um "espírito novo" (FONSECA, 2006).

Mas não somente de alinhamentos e concordâncias com prescrições oficiais era feita a história durante o Estado Novo. Marc Bloch nos alerta que "[...] mesmo o mais claro dos documentos não fala senão quando se sabe interrogá-lo. É a pergunta que fazemos que condiciona a análise e, no limite, eleva ou diminui a importância de um texto retirado de um momento afastado" (BLOCH, 2001, p. 7). Ou seja, a necessidade da interrogação das fontes decorre do desejo de ir além do que está exposto à primeira vista. Nesse sentido, também encontramos nas fontes possibilidades de desvios quanto ao que era oficialmente determinado. É o que lemos na coluna intitulada "A criança, a maior vítima do comunismo", publicada no jornal Diário da Manhã do dia 10 de dezembro de 1937. De acordo com a publicação, Getúlio Vargas concedeu entrevista a um correspondente de um jornal de Roma, replicada 
pela imprensa da capital brasileira, em que dedicou à criança o capítulo final, esclarecendo o "grandioso plano" que seria colocado em vigor durante seu governo com o objetivo de defender o bem-estar da família e garantir a grandeza do futuro da Pátria. O conteúdo da entrevista revelava que, com Vargas no governo, não se permitiria que germinasse no Brasil a praga da desagregação moral da juventude, pregada pelos comunistas sob o rótulo atraente de "liberdade absoluta". Para o chefe da nação, a educação moral e cívica, o conceito de nacionalidade e o cuidado com o estado físico das crianças eram dedicadamente amparados pelo Estado. Vargas declara:

Cumpre, pois, que pais e mães brasileiras deem ao Chefe da Nação sua assistência continuada a essa obra grandiosa. Trata-se, sobretudo, de uma legítima defesa de cada um contra a invasão de seu lar por doutrinas perigosas e destruidoras. Para essa defesa, que mais diretamente interessa aos próprios pais é que o governo vai dirigir seus esforços. Olhemos os exemplos que se apresentam na Rússia e na Espanha sovietizada. A noção de Pátria desapareceu. O amor ao lar, aos pais, aos filhos transformou-se em um amor exclusivo às liberdades desregradas. Defendamos nosso patrimônio moral tão valioso ou, pelas condições naturais do nosso país, estaremos nas mãos dos técnicos da desordem e da desgraça transformados em uma nação em que o destino regerá as normas de cada um. E pela vastidão do nosso território, pelo problema econômico que nos assoberba, um Brasil soviético será mil vezes desgraçada do que a própria infeliz Rússia. (VARGAS, 1937).

A necessidade de Getúlio Vargas fazer circular na imprensa de grande alcance, como um jornal de publicação diária, uma entrevista em que combatia valores que divergiam de seu ideal patriótico, como eram os ideais comunistas, indica que, em alguma proporção, existia resistência ao projeto de nação pretendida. A presença do discurso contra uma suposta ameaça comunista que se opunha verticalmente à construção patriótica ufanista, característica do governo varguista, sinaliza a possível existência de uma oposição que incomodava Getúlio Vargas ao ponto de que se sentisse ameaçado em sua atuação política.

A formação do "espírito nacional" por meio de uma narrativa história cívica e patriótica é uma tônica do período varguista, principalmente pós-37, como mostram os documentos analisados. Contudo, a leitura dos textos e, principalmente, do hors texte (GINZBURG, 2007) nos permitiram ler outros movimentos subterrâneos e, por vezes, sutis, em que modos de pensar e agir distintos dos previstos por um ideário patriótico se manifestaram e, por consequência, "ameaçaram" o projeto de nação em curso.

\section{Entre expectativas oficializadas e a história ensinada em escolas capixabas durante a Ditadura civil-militar (1964-1985)}

Em estudo desenvolvido sobre o ensino de História em escolas capixabas durante a Ditadura civil-militar ${ }^{14}$, analisamos documentos produzidos no âmbito do Ministério da Educação e da Cultura (Cadernos MEC e Guia Metodológico), propostas curriculares elaboradas pela Secretaria Estadual de Educação do Espírito Santo, atas de reuniões pedagógicas, material de cursos oferecidos a professores e diretores escolares, publicações da imprensa periódica local, registros de práticas e narrativas de professores que atuaram com a disciplina História e Estudos Sociais no período. Na análise cruzada desse conjunto de documentos, emergiram indícios do escolanovismo, ${ }^{15}$ do tecnicismo ${ }^{16}$ e de práticas voltadas para um ensino de História pouco contextualizado.

\footnotetext{
${ }^{14}$ Este tópico do artigo parte de resultados de Tese de Doutorado intitulada Dentro e fora da ordem: diretrizes curriculares para o ensino de História em tempos autoritários (1964-1985), defendida no Programa de Pós-Graduação em Educação da Universidade Federal do Espírito Santo em 2015

$15 \mathrm{O}$ escolanovismo, em linhas gerais, postula uma escola voltada para a integração dos alunos ao meio social, preparando-os para os desafios da sociedade; enfatiza o material e os recursos didáticos, tomando como fator primordial para a aprendizagem o interesse do aluno (LUIZ, 2015).

${ }^{16}$ Germano (2011, p. 105-106) caracteriza a política educacional do período a partir de elementos vinculados à teoria do capital humano, que coincide com noções do tecnicismo, como o controle político e ideológico da educação escolar, em todos os níveis, o estabelecimento de uma relação direta e imediata entre educação e produção capitalista, além do Educação em Revista|Belo Horizonte|v.36|e225224|2020
} 
Não obstante, é possível identificar em escolas capixabas marcas de um ensino de cunho cívico, patriótico e ufanista. Debruçando-nos, portanto, sobre esse corpus documental, investigamos os contornos assumidos pelo civismo nesse cenário. A partir dos objetivos delineados pelos manuais didáticos, propostas curriculares, guias metodológicos e expressos nos registros de práticas e narrativas docentes, ${ }^{17}$ como o discurso cívico aparece na História prescrita e ensinada em escolas capixabas? Ensinar História no período aqui referenciado (1964-1985) - compreendido por Schmidt (2012) como momento de crise dessa disciplina - significava ensinar Estudos Sociais, que fundia História e Geografia, além do acréscimo de Educação Moral e Cívica e Organização Social e Política Brasileira. Isso porque com a Lei $5692 / 71$ essas disciplinas passaram a compor obrigatoriamente o currículo de todo o $1^{\circ}$ grau e, com a redução da carga horária da História e da Geografia e a ausência de professores formados nessas "novas" disciplinas, os professores dessas duas áreas

[...] passaram a envolver-se, diretamente, ao ministrar as duas disciplinas [Educação Moral e Cívica e Organização Social e Política Brasileira, além dos Estudos Sociais], na medida que o conteúdo e os conceitos de moral e civismo perpassavam todas as disciplinas e atividades extraclasse [...]. (FONSECA, 2003, p. 21-22)

Portanto, para a operação historiográfica proposta, consideramos a área dos Estudos Sociais como locus de efetivação dos estudos da História e, portanto, analisamos os modos de pensar, produzir e ensinar esse componente curricular. Sabemos que não é exclusividade desse período o ensino dessa disciplina, pois desde a década de 1930 já estava sendo "experimentada" na Escola Primária (BITTENCOURT, 2009; FONSECA, 2006), porém é a partir de 1971 que seu ensino se torna obrigatório.

No conjunto dos documentos do período, chama-nos a atenção atas de reuniões pedagógicas das escolas primárias do município de Colatina, como é o caso dos registros de reuniões das Escolas Reunidas Pedro Vitali, do ano de 1968. Em três das seis reuniões registradas, procedeu-se à leitura do livro: O ensino da geografia e da história na escola primária, de autoria de Nilda Bethlen (196-).

Perseguindo pistas do civismo nas escolas capixabas, analisamos detalhadamente o conteúdo da obra de Bethlen (196-), principalmente por ela ter referenciado a elaboração do Currículo para o Ensino Primário no Espírito Santo (1969), além de seu conteúdo ter se constituído em tema de estudo em reuniões pedagógicas. Ao focalizar o civismo, percebemos sua estreita relação com os Estudos Sociais e os modos como se configurou seu ensino nas escolas brasileiras ao longo do século XX.

Bethlem discute o âmbito e o conceito dos Estudos Sociais, definindo-o como um campo de estudos, uma união de assuntos, que trata, de uma forma ou de outra, das relações entre os seres humanos. Sob essa denominação, estariam a História, a Geografia, o Civismo e todas as atividades escolares de caráter social.

Nessa perspectiva, encontram-se incluídos: a) o Civismo por tratar de direitos e deveres do cidadão, relações do indivíduo com seus dirigentes, dentre outros; b) a História porque narra, comenta e procura explicar os fracassos e sucessos do homem através dos tempos, portanto, dos principais acontecimentos que constituem a vida política, econômica, intelectual e moral de um povo; c) a Geografia por tratar das relações entre o homem e o meio, propicia ao educando um conhecimento sobre o real valor dos povos, seus reajustamentos e vitórias, levando-o a atitudes de tolerância e cooperação nacional e internacional (BETHLEM, 196-).

A autora apresenta, ainda, a natureza dos objetivos dos Estudos Sociais na escola primária, dispondo-os em quatro categorias: humana, social, cívica e informativa e intelectual. Pela análise dos objetivos propostos, compreendemos que a concepção de História presente na obra constitui-se de elementos voltados para uma abordagem administrativa, de feição ufanista, em que se privilegia a geografia física, comportamentos necessários à integração do sujeito ao meio social, bem como a uma

descomprometimento com o financiamento da educação pública e gratuita, transformando-a em negócio rendoso e subsidiado pelo Estado.

${ }^{17}$ Narrativas de três professores que atuaram em escolas capixabas durante esse período compõem esse artigo e serão identificadas por nomes fictícios. As entrevistas foram realizadas em 2014. 
vertente cívica, explicitada nos objetivos: “[...] aprender a amar sua pátria; entender e viver democraticamente; entender as funções de um governo e seus problemas; saber como a opinião pública é formada; como se vota, como se fazem as leis e como se elege um representante do povo" (BETHLEM, [196-], p. 31).

Trata-se da História sintetizada à disciplina de Estudos Sociais, cujos objetivos deveriam estar em harmonia com os da própria escola primária, que, conforme a autora, também se harmonizariam com os objetivos nacionais.

Ao buscar uma harmonização com objetivos nacionais da época, os princípios de moral e civismo perpassavam as disciplinas curriculares, bem como os Estudos Sociais, que retiravam da História e da Geografia seus métodos próprios de produção de conhecimento. Para Mendes, tratava-se de disciplinas "[...] fetichizadas, submetidas à estratégia política para dissolver as necessidades reais: os salários, a alimentação, a habitação, a comunicação cultural e política livre, encobrindo conflitos e mascarando a estratificação social” (1998, p. 87).

No conjunto de ações do Estado para intervir na educação do período - Lei 5692/71, Reforma Universitária (Lei 5440/1968), inclusão e exclusão de componentes curriculares, comemorações públicas de efemérides, publicações paradidáticas e os manuais financiados pela Fundação Nacional do Material Escolar (Fename) -, há uma tendência em oferecer "guias", normatizações e orientações/diretrizes aos professores e às escolas para o trabalho pedagógico: “[...] os 'guias' [estão] mais associados ao regime militar, referenciado como elemento de uma prática e um discurso autoritários" (MARTINS, 2007, p. 34). Processos de produção de documentos prescritivos para o ensino de História constituem, portanto, modos de intervenção exercida pelo Estado autoritário.

O Guia Metodológico para Cadernos MEC (GASMAN; FONSECA, 1971) ${ }^{18}$ insere-se nessa perspectiva intervencionista. Humberto Grande (1971), diretor executivo da Fename, ao prefaciar, sugere que a obra objetivava impulsionar os estudos da História como disciplina capaz de relacionar o sentimento nacional, com o sentimento internacional. Portanto, a ênfase a esse patriotismo defendido no período parece-nos intimamente vinculado à noção de civismo incorporado aos discursos e ações dos intelectuais atuantes no MEC.

Para os intelectuais no interior do MEC, a elaboração de políticas culturais e educacionais sistemáticas era fundamental na preservação e divulgação do patrimônio e da memória nacional e, para os governos militares essa visão conservadora e otimista da cultura e da educação forneceria as bases da construção da consciência cívica dos cidadãos. (MAIA, 2013, p. 3)

Com assessoria do MEC em sua elaboração, o documento "Orientações Curriculares" para a disciplina Estudos Sociais, publicado pela Secretaria de Educação em 1978, é também um exemplo de um tipo de "guia" que visava "[...] direcionar as atividades das Escolas de 1 Grau do Estado do Espírito Santo no manuseio e aplicação da Proposta Curricular de Estudos Sociais [de 1974]" (ESPÍRITO SANTO, 1978, p. 1).

Ao tratar da área Estudos Sociais, o documento orienta que os objetivos sejam formulados ao considerar: organização social e política, aspectos geográficos e históricos, aspectos econômicos e aspectos de moral e civismo. "Assim, o aluno, desde as séries iniciais irá realizando aprendizagens que lhe darão o embasamento necessário à vida e à convivência em comunidade" (Ibidem, p. 24).

Como acréscimo ao civismo proposto no âmbito das disciplinas - Estudos Sociais, Educação Moral e Cívica e Organização Social e Política Brasileira -, o documento orientador de 1978 apontou o Centro Cívico como importante atividade extraclasse: "Nas escolas da Rede Oficial de nosso Sistema de Ensino a criação dos Centros Cívicos é obrigatória [...]. Será o Centro Cívico, então, a primeira atividade extra-classe criada na escola e que, além de responder a disposições legais, oferecerá a vantagem de estimular a adesão dos alunos a outras atividades" (Ibidem, p. 68-69).

\footnotetext{
${ }^{18}$ Para orientar os usos dos Cadernos MEC de História Geral, a Fename publicou o Guia metodológico em 1971 com objetivo de preparar pedagogicamente os professores tendo em vista às necessidades da renovação da escola de nível médio em face da realidade nacional (GRANDE apud LUIZ, 2015, p. 186). 
Além dos documentos prescritivos e obras didáticas até aqui apontadas, lemos, em publicações periódicas locais e registros escolares, feições de ordem cívica e patriótica. É o caso, por exemplo, da publicação do jornal A Gazeta, de 10 de julho de 1965:

\section{Desfile foi mensagem de civismo}

Emprestando o ar da graça e ineditismo, desfilou perante a população capixaba, no último dia da Independência, a Banda da Escola Normal D. Pedro II, responsável por uma das maiores manifestações de simpatia e apreço de quantos assistiram ao desfile. As garbosas estudantes do tradicional estabelecimento oficial de ensino foram vivamente aplaudidas e muito comentada foi sua 'performance'.

A Banda do 'Pedro II' brilhou.

Na mesma direção, segue a publicação de 4 de setembro de 1971:

Capixabas foram à avenida aplaudir desfile escolar

'A festa foi bonita e até a chuva parou para o desfile'

Em frente ao palanque, o Instituto de Educação

O capixaba mais uma vez se fez presente ao longo da avenida Jerônimo Monteiro, a fim de assistir ao desfile cívico escolar em comemoração à Semana da Pátria. Às 6 horas a afluência já era grande com o povo acomodando-se visando conseguir um bom local para assistir ao espetáculo. A chuva de papel picado e bandeiras hasteadas nas casas comerciais constituíram novamente um motivo para renovar o sentimento patriótico de civismo e amor à Pátria [...].

O discurso político, imbuído de valores e simbologias cívico-morais, ganhava contornos em meio a um conjunto de práticas educativas que complementavam a formação do jovem cidadão (GOMES, 2009a; MAIA, 2013). As datas comemorativas registradas nas atas das reuniões pedagógicas das escolas reunidas do município de Colatina indiciam a preocupação com a promoção do espírito patriótico e cívico. Das 30 reuniões registradas no Livro de Atas dessa instituição (1967 a 1974), 14 tinham em suas pautas a preparação de programações atinentes a datas cívicas e comemorativas. Nos registros, além das programações, observamos a leitura de circulares enviadas pela Secretaria de Educação, exigindo que as comemorações fossem incorporadas à vida escolar. Em reunião realizada em 30 de agosto de 1969, fez-se o seguinte registro:

Um dos assuntos em pauta foi o Programa Comemorativo da Semana da Pátria. Dando início a Sra diretora disse: o objetivo da nossa reunião é falar sôbre a programação da data 7 de setembro. Depois foi lida a circular $\mathrm{n}^{\circ} 8$ que abordava assuntos relacionados com a mencionada data. Prosseguindo leu para as professôras presentes o programa que deverá ser elaborado por ocasião dos festejos da Pátria (sic). (ESCOLAS REUNIDAS PEDRO VITALI. Ata da reunião realizada em 30 de agosto de 1969)

Em $1^{\circ}$ de agosto de 1970, lê-se: “[...] Finalmente [a diretora] falou sôbre as datas comemorativas do mês que merecem nossa atenção fazendo despertar na criança o amor, a dedicação e respeito pelos seus pais e também pela Pátria através do exemplo do nosso pacificador Duque de Caxias [...]" (ESCOLAS REUNIDAS PEDRO VITALI. Ata da reunião realizada em $1^{\circ}$ de agosto de 1970). Em relação à reunião do dia 30 de agosto de 1973, registrou-se:

[...] Iniciando a reunião a diretora falou sôbre o planejamento do mês de setembro, incluindo os festejos da semana da Pátria. [...] dia 7, nossos alunos desfilarão pelas ruas da cidade, encerrando assim as homenagens prestadas aos grandes vultos patriotas, que no passado lutaram para a conquista de um Brasil livre e independente [...]. Continuando leu a circular $n^{\circ} 1 / 73$, do Departamento Técnico Educacional, que fala sobre as festividades da Semana da Pátria e o Centenário do Nascimento de Alberto Santos Dumont, tais comemorações deverão contribuir para desenvolver o espírito patriótico [...]. (ESCOLAS REUNIDAS PEDRO VITALI. Ata da reunião realizada em 30 de agosto de 1973, grifos nossos)

Um nexo possível do papel que as escolas, com orientações da Secretaria de Educação, atribuíam a uma educação cívica pode ser observado ao analisarmos o material dos Estágios de Educação em Revista|Belo Horizonte|v.36|e225224|2020 
Treinamento em Recursos Audiovisuais (BARBOSA, 1967-1971) 19. As "matérias" de História, Geografia e Moral e Cívica foram numericamente superiores às demais produzidas pelo Departamento de Recursos Audiovisuais (DRA), em 1970, momento especialmente duro dentro do quadro ditatorial brasileiro: História teve 963 unidades, Geografia 2.061 e Moral e Cívica 622. Em 1971, para a área de História, foram produzidos boletins informativos e apostilas sobre: Folclore, Proclamação da República, Dia do Soldado, Anchieta, Independência do Brasil e Semana da Asa. Registra-se, no mesmo período, o concurso promovido pelo Departamento: Faça sua Bandeira. As atividades planejadas para 1971 incluíram a produção de painéis e materiais didáticos: Semana da Criança, Dia do Soldado, Dia do Papai, Dia das Mães, Páscoa, Semana da Pátria, Nações Unidas, Tiradentes, Proclamação da República e Natal.

O que encontramos nas escolas estaduais referente à disciplina de História relacionada com a atuação do DRA voltava-se para datas cívicas e comemorativas, bem como para os símbolos pátrios mantendo-se o foco nos recursos materiais que poderiam ser utilizados no contexto das salas de aulas, em qualquer disciplina - a partir disso, é inegável a presença do tecnicismo nesse período.

A leitura do conjunto das fontes contribuiu para ampliar interrogações e compreensões acerca das feições que o civismo assumiu na História ensinada nesse período. Em meio à análise cruzada da documentação, rastreamos o ufanismo patriótico acentuado sob o regime militar, que evidenciam elementos, como o nacionalismo, civismo e autoritarismo (CHAUÍ, 2001), elementos presentes na História brasileira desde o século XIX difundidos, dentre outros veículos, pelo ensino de História (BITTENCOURT, 2008; FONSECA, 2006).

Assim, da documentação analisada, emergiram convergências a respeito do ensino de História nas escolas capixabas com estudos da área (ALMEIDA NETO, 1996; MIMESSE, 2007, 2008; LOURENÇO, 2006, 2008; ANDRADE, 2009) que apontam para a irradiação de documentos emanados do Ministério da Educação e das Secretarias Estaduais com acentuado apelo ao civismo. Daí a relevância, para além de livros didáticos e diretrizes curriculares, de levarmos em conta igualmente a História construída e legitimada pela prática e experiência dos professores.

Passamos a ler, nesse sentido, registros de práticas sem vinculação visível com as diretrizes estabelecidas para o ensino das disciplinas curriculares. Relatos de professores que atuaram com História e Estudos Sociais à época elucidam o distanciamento e mesmo a crítica de professores às diretrizes propostas.

Essas propostas curriculares [referindo-se às propostas estaduais] não eram distribuídas a cada professor. Mantinham-se alguns exemplares na escola para que pudéssemos ler. Fazíamos pequenos estudos em grupos. Em relação à formação continuada, aqui, em Santa Teresa, só aconteceu depois da ditadura e eram realizadas sem objetivos específicos. Eram realizadas porque a verba para esse propósito tinha que ser gasta. Não havia profissionais que se dispusessem a ministrar, até porque também não conheciam, com propriedade, o conteúdo. Andávamos meio às cegas [...]. Enfrentávamos dificuldades de orientações pedagógicas e cada um ministrava suas aulas conforme achava melhor. (MANOEL, 2014)

Em perspectiva similar, as falas de Vera evidenciam distanciamentos das prescrições para o ensino nas escolas: "Em frente ao pátio da escola tinha a quadra, a gente pegava as carteiras e ficava no sol ali, cedinho e os alunos gostavam... E eu tinha um método prático de corte e costura, que eu aprendi na primeira vez que eu dei aula no interior, ensinei para as alunas [...] e para colegas [...]" (VERA, 2014).

Ao "inventar moda" (VERA, 2014), o que havia de cívico e patriótico em um curso de corte $e$ costura? Em que medida atendia às prescrições vigentes à época?

Referindo-se às disciplinas de Educação Moral e Cívica e Organização Social e Política Brasileira cursadas na condição de aluno, o professor Manoel considera que "[...] nunca formaram cidadãos, pelo contrário, eram ministradas de forma metódica que nos forçava apenas a decorar hinos, armas e brasões, um terror. Faltou-nos dialética" (MANOEL, 2014).

\footnotetext{
19 Trata-se de uma compilação de registros dos Estágios de Treinamento em Recursos Audiovisuais para professores primários e pré-primários capixabas produzidos pela chefe do Departamento de Recursos Audiovisuais (DRA). 
Manoel, que atuou como professor mesmo antes da graduação, percebia que a disciplina História era ensinada de forma fragmentada, factual, sem qualquer tipo de análise ou crítica. Isso o incomodava, porque

[...] entendia que as aulas de História tinham que ter uma dimensão muito maior do que apenas os livros didáticos. Foi necessário então aplicar a ludicidade para que os alunos pudessem 'entender' a disciplina de forma orgânica, como sujeitos da própria história. Minhas aulas se desenvolviam com mais coerência e emoção. (MANOEL, 2014)

Esse professor revela, portanto, indícios de um ensino distante do prescrito, ao conferir-lhe uma dimensão crítica e problematizadora. Em suas palavras: "Minhas questões, numa eventual avaliação, eram absolutamente reflexivas e instigantes. Forçava-os a pensar" (MANOEL, 2014, grifos nossos).

Fotografia encontrada (Imagem 2) na Escola Estadual Professor Fernando Duarte Rabelo dão-nos pistas também de práticas desviantes quanto às intenções curriculares oficializadas:

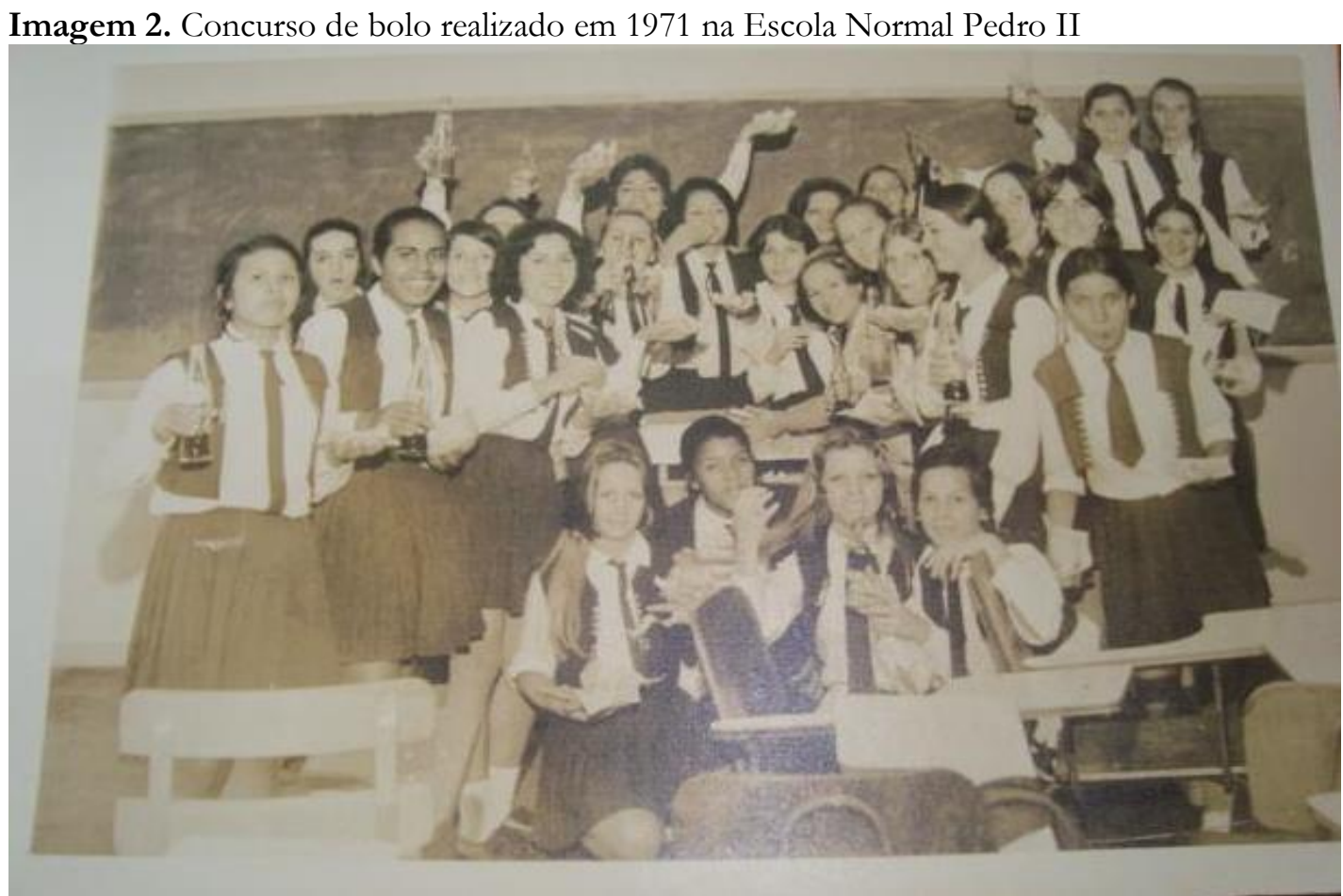

Fonte: Secretaria da Escola Estadual Professor Fernando Duarte Rabelo (2013).

Assim como esta, tantas outras imagens que se perderam no tempo ajudam-nos a pensar outros fazeres da/na escola. Permitem-nos pensar, também, como esses sujeitos davam a ver práticas que se distanciavam das expectativas oficializadas.

Entre atividades de Corte e Costura e o Concurso de Bolo, não há como ignorar depoimentos como o da professora Telma, que desaconselham uma leitura homogeneizadora do ensino de História no período estudado: "Então privilegiávamos o Programa, mas dávamos também outras atividades, usando muito o recurso audiovisual" (TELMA, 2014). Afinal, como nos lembra Bloch (2001), é aconselhável que a ciência extrapole a simples descrição do que a constitui enquanto tal. Portanto, há distintas facetas da História ensinada a serem localizadas e problematizadas por meio dos rastros e fios (GINZBURG, 2007) deixados pelos sujeitos escolares.

\section{CONSIDERAÇÕES FINAIS}

Historicamente, a área de Ciências Humanas tem sido alvo da intervenção do Estado, seja em sua feição assumidamente autoritária ou em períodos com certa experiência liberal-democrática. Essa preocupação do Estado fica evidente ao analisarmos as diretrizes curriculares, manuais didáticos e ao 
escutarmos as narrativas de professores sobre o ensino de História nos períodos investigados e, portanto, exige-se que levemos em conta a força do estado ditatorial brasileiro. Por outro lado, apontamentos como os de Laville (1999) provocam-nos a considerar paradoxos relativos à forma como o ensino de História tem sido pensado pelo Estado e pela sociedade. Um desses paradoxos seria a ênfase curricular à autonomia intelectual e o pensamento crítico nos programas escolares para o ensino de História - que ele observou em escolas "de quase todo o mundo" - em detrimento da missão de incutir nas consciências uma narrativa única, glorificando a nação ou a comunidade. No entanto, segundo o autor, essa narrativa única continua sendo o alvo privilegiado de debates, embora não as tenha percebido nos programas curriculares analisados.

Ainda a partir de análises de experiências de diferentes países, dentre eles, o Brasil, Laville (1999) aponta a existência de outro paradoxo, que decorre do primeiro e consiste em acreditar que, pela manipulação dos conteúdos, seja possível dirigir as consciências ou as memórias, quando a experiência do século XX indica que, provavelmente, essa crença não passe de uma grande ilusão.

Em meio às prescrições, aos registros de práticas e mesmo aos paradoxos que possam acompanhar o ensino de História, neste artigo, buscamos compreender os contornos que o civismo assumiu durante o Estado Novo (1937-1945) e a Ditadura Civil-militar (1964-1985). A análise do conjunto de documentos apontou para uma compreensão inequívoca: a julgar pelos documentos prescritivos, manuais didáticos e ofícios emanados do Ministério da Educação e das Secretarias Estaduais, é perceptível, por um lado, a intervenção do Estado no que se refere ao ensino nas escolas, especialmente da História e, por outro, a ênfase ao civismo e ao patriotismo materializados nesses documentos.

Identificamos, portanto, o discurso político revestido de valores e simbologias cívico-morais em meio a um conjunto de práticas educativas que complementavam a formação do jovem cidadão (GOMES, 2009a; MAIA, 2013). Concordamos com Gomes (2009a) ao afirmar que o "espírito nacional" idealizado e difundido no Estado Novo passa a ser incorporado ao projeto cívico dos intelectuais e técnicos atuantes no MEC, sob a ótica da necessidade de formação de uma "consciência cívica", considerada fundamental nas relações entre o Estado e a sociedade civil. Porém, a leitura das fontes "a contrapelo" (GINZBURG, 2007) revela pistas de uma educação desviante da perspectiva cívica pretendida. É o caso da coluna intitulada "A criança, a maior vítima do comunismo", publicada no jornal Diário da Manbã do dia 10 de dezembro de 1937, que marca a existência de uma oposição que incomodava Getúlio Vargas, revelando-se como ameaça para sua atuação política. No caso específico das escolas capixabas, observamos como singularidades, indícios de práticas distintas do prescrito para o Ensino de História, como as críticas dos professores às propostas curriculares elaboradas principalmente na década de 1970, a defesa por um ensino de História reflexivo e instigante, além dos concursos de bolo e aulas de corte e costura que revelam distintas faces da História ensinada em tempos autoritários.

Em meio aos atuais discursos em defesa, por um lado, de uma educação cívica e, por outro, contra a educação política dos jovens, como historiadoras e professoras de História, colocamo-nos diante dos paradoxos apontados por Laville (1999) a respeito das expectativas em torno do Ensino da História, dos debates sobre seus objetivos e, sobretudo, dos impactos desse ensino na vida das pessoas, em particular e na sociedade, de modo amplo. Dessa maneira, diante das incertezas da História, das ilusões em torno de seu ensino e das promessas a respeito do futuro, assumimos a compreensão de Bloch (2001, p. 63) ao aconselhar que a análise de tais narrativas seja feita à luz do passado, porém, com interrogações situadas no presente, pois: "[...] a ignorância do passado não se limita a compreensão do presente, compromete, no presente, a própria ação". Além disso, o autor adverte e, concordamos com sua premissa de que, seria uma vã ilusão compreender o passado se nada sabemos a respeito do presente.

\section{REFERÊNCIAS}

ALMEIDA NETO, Antonio S. O ensino de história no período militar: práticas e cultura escolar. 1996. 216 f. Dissertação (Mestrado em Didática) - Faculdade de Educação da Universidade de São Paulo, São Paulo, 1996. Disponível em: www.capes.gov.br. Acesso em: 2 jun. 2019. 
ANDRADE, Raquel de Sá. Professores de história no período pós-1964: percursos e práticas. 2009. 171 f. Dissertação (Mestrado em Educação) - Pontifícia Universidade Católica de Minas Gerais, Belo Horizonte, 2009. Disponível em: www.capes.gov.br. Acesso em: 2 jun. 2019.

BARBOSA, Lacy Loyola. Relatório do Departamento de Recursos Audiovisuais do Espírito Santo acerca dos Estágios de Treinamentos em Recursos Audiovisuais (ETRA) destinados a professores capixabas (1967-1971). Vitória: Departamento de Recursos Audiovisuais do Espírito Santo.

BITTENCOURT, Circe Maria Fernandes. Ensino de história: fundamentos e métodos. 3. ed. São Paulo: Cortez, 2009.

BITTENCOURT, Circe Maria Fernandes. Capitalismo e cidadania nas atuais propostas curriculares de história. In: BITTENCOURT, Circe Maria Fernandes. O saber histórico na sala de aula. São Paulo: Contexto, 2008. p. 11-27.

BETHLEM, Nilda. O ensino da geografia e da história na escola primária. 4. ed. [s.l.]: J. Ozon editor, [196?].

BLOCH, Marc Leopold Benjamin. Apologia da história, ou o ofício do historiador. Tradução de André Telles. Rio de Janeiro: Jorge Zahar Ed., 2001.

BORGES, Ernesto Charpinel; SALIM, Maria Alayde Alcantara. Ensino de História no Brasil: tensões do presente ao passado. Kiri-kerê: Pesquisa em Ensino, n. 2, maio 2017. p. 65-88.

CAPIXABAS foram à avenida aplaudir desfile escolar. A Gazeta, Vitória, 4 set. 1971.

CARVALHO, José Murilo. Pontos e bordados: escritos de história e política. Belo Horizonte: Editora da UFMG, 1999.

CHAUÍ, Marilena de Souza. Ventos do progresso: a universidade administrada. In: CHAUÍ, Marilena de Souza. Escritos sobre a universidade. São Paulo: Editora Unesp, 2001. p. 43-72.

DESFILE foi mensagem de civismo. A Gazeta, Vitória, 10 jul. 1965.

ESCOLA DONA MARIA MATOS. Prova realizada em 25 de novembro de 1940 na escola D. Maria Matos. Anchieta: Escola D. Maria Matos, 1940.

ESCOLA SANTA ROSA. Prova de história pátria realizada em 14 de novembro de 1940. Espírito Santo: Escola Santa Rosa, 1940.

ESCOLAS REUNIDAS PEDRO VITALI. Ata da reunião realizada em 30 de outubro de 1968. Colatina: Escolas Reunidas Pedro Vitali, 1968.

ESCOLAS REUNIDAS PEDRO VITALI. Ata da reunião realizada em 30 de outubro de 1968. Colatina: Escolas Reunidas Pedro Vitali, 1970.

ESCOLAS REUNIDAS PEDRO VITALI. Ata da reunião realizada em 30 de outubro de 1968. Colatina: Escolas Reunidas Pedro Vitali, 1973.

ESTADO DO ESPÍRITO SANTO. Orientações curriculares: estudos sociais. Vitória: Secretaria de Estado da Educação e Cultura, 1978. 
FARIA, Paula Florinda de Freitas. O ensino de História no Ginásio do Espírito Santo durante o Estado Novo (1945-1945). Dissertação em elaboração no Programa de Pós-Graduação em Educação da Universidade Federal do Espírito Santo com previsão de publicação para 2019. Vitória.

FICO, Carlos. 1964: 50 anos depois. Entrevista cedida a Bruno Leal, do Café História TV, em 15 de janeiro de 2014.2 Disponível em: https://www.youtube.com/watch?v=Dm6J7kc3DBc\&list=PL9kEowC2xzmeEQdqyScnAb1 ey30Ov_ Dnv. Acesso em: 2 jan. 2019.

FONSECA, Selva Guimarães. Didática e prática de ensino de história. São Paulo: Papirus, 2003.

FONSECA, Thaís Nívea de Lima. História \& ensino de história. Belo Horizonte: Autêntica, 2006.

GASMAN, Lydinéa; FONSECA, James B. Guia metodológico para cadernos MEC: história. Rio de Janeiro: Ministério da Educação e Cultura/Fundação Nacional de Material Escolar (Fename), 1971b.

GERMANO, José Willington. Estado militar e educação no Brasil (1964-1985). 5. ed. São Paulo: Cortez, 2011.

GINÁSIO DO ESPÍRITO SANTO. Lista de pontos de prova de História do Brasil. Vitória: Ginásio do Espírito Santo, 1940.

GINZBURG, Carlo. O fio e os rastros: verdadeiro, falso, fictício. São Paulo: Companhia das Letras, 2007.

GINZBURG, Carlo. Relações de força: história, retórica e prova. 1. reimpressão. São Paulo: Companhia das Letras, 2002.

GOMES, Angela de Castro. Venturas e desventuras de uma república de cidadãos. In: ABREU, Martha; Rachel Soihet (Org.). Ensino de História: conceitos, temáticas e metodologia. 2. ed. Rio de Janeiro: Casa da palavra, 2009b. p. 152-167.

GOMES, Angela de Castro. República, educação cívica e história pátria: Brasil e Portugal. In: SIMPÓSIO NACIONAL DE HISTÓRIA: História e Ética, 25. Fortaleza, UFC, 2009. Anais eletrônicos... Disponível em: http://multimediadesignstudio.com.br/demo//uploads/files/1534015346_2145b2a8c9bd168f7cc76c2 d809eea0f.pdf. Acesso em: 3 mai. 2019a.

GRANDE, Humberto. Prefácio. In: GASMAN, Lydinéa; FONSECA, James B. Vieira da. Guia metodológico para cadernos MEC: história. Rio de Janeiro: Ministério da Educação e Cultura/Fundação Nacional de Material Escolar (Fename), 1971. p. 4-8.

GRUPO ESCOLAR CORONEL ANTÔNIO DUARTE. Planejamento de aula. Iconha: Grupo Escolar Coronel Antônio Duarte, 1938.

GRUPO ESCOLAR CORONEL XAVIER. Relatório enviado a Fernando Duarte Rabelo em 22 de novembro de 1938. Sabino Pessoa: Grupo Escolar Coronel Xavier, 1938.

LAVILLE, Christian. A guerra das narrativas: debates e ilusões em torno do ensino de história. Revista Brasileira de História. São Paulo, v. 19, n. 38, p. 125-138, 1999. Disponível em: http://www.scielo.br/scielo.php?script=sci_arttext\&pid=S0102-01881999000200006. Acesso em: 14 abr. 2019. 
LOURENÇO, Elaine. A formação docente entre a legislação e o currículo: história e estudos sociais nos anos 1970. In: ENCONTRO NACIONAL DE PESQUISADORES EM ENSINO DE HISTÓRIA, 7., 2006. Belo Horizonte. Anais... Belo Horizonte: UFMG, 2006. 1 CD-ROM.

LOURENÇO, Elaine. Os grupos escolares do Estado de São Paulo nos anos de 1970: Entre CERHUPE e a CENP. In: ENCONTRO NACIONAL DE PESQUISADORES EM ENSINO DE HISTÓRIA. 8., 2008. Anais... São Paulo: Feusp, 2008. 1 CD-ROM.

LUIZ, Miriã Lúcia. Dentro e fora da ordem: diretrizes curriculares para o ensino de História em tempos autoritários (1964-1985). 2015. 206f. Tese (Doutorado em Educação) - Programa de Pós-Graduação em Educação, Universidade Federal do Espírito Santo, Vitória, 2015.

MAIA, Tatyana de Amaral. Civismo e cidadania num regime de exceção: o conhecimento histórico ensinado e seus usos políticos na ditadura civil-militar (1969-1985). In: SIMPÓSIO NACIONAL DE HISTÓRIA DA ANPUH: Conhecimento histórico e diálogo nacional, 27., Natal, 2013. Anais eletrônicos... Disponível em: www.snh2013.anpuh.org/.../1363710953_ARQUIVO_artigoANPUHTatyanaMaia.pdf. Acesso em: 14 abr. 2019.

MANOEL. Ensino de História durante a Ditadura Militar no Espírito Santo. 2014. Entrevista concedida para elaboração de tese de doutorado desenvolvida no Programa de Pós-Graduação em Educação da Universidade Federal do Espírito Santo, Vitória, 2014.

MARTINS, Maria do Carmo. Currículo, cultura e ideologia na ditadura militar brasileira: demarcação do espaço de atuação do professor. In: CERRI, Luis Fernando (Org.). O ensino de história e a ditadura militar. 2. ed. Curitiba: Aos Quatro Ventos, 2007. p. 29-46.

MENDES, Durmeval Trigueiro. Existe uma filosofia da educação brasileira? In: MENDES, Durmeval Trigueiro (Coord.). Filosofia da educação brasileira. 6. ed. Rio de Janeiro: Civilização Brasileira, 1998.

MIMESSE, Eliane. O ensino profissional obrigatório de $2^{\circ}$ grau nas décadas de 70 e 80 e as aulas dos professores de história. Revista HISTEDBR on-line, Campinas, n. 26, p. 105-113, jun. 2007. Disponível em: http://www.histedbr.fae.unicamp.br. Acesso em: 23 set. 2013.

MIMESSE, Eliane. As avaliações aplicadas pelos professores na disciplina história nas décadas de 1970 e 1980. Revista HISTEDBR on-line, Campinas, n. 30, p. 119-132, jun. 2008. Disponível em: http://www.histedbr.fae.unicamp.br. Acesso em: 23 set. 2013.

NUNES, Clarice. As políticas públicas de educação de Gustavo Capanema. In: BOMENY, Helena (Org.). Constelação Capanema: intelectuais e políticas. Rio de Janeiro: Editora FGV, 2001.

OlIVEIRA, Lúcia Lippi; VELlOSO, Mônica Pimenta; GOMES, Ângela Maria de Castro. Estado Novo: ideologia poder. Rio Janeiro: Zahar Ed., 1982.

OLIVEIRA, Renato Edson. O Brasil imaginado em José Francisco da Rocha Pombo. Dissertação. 2015. Dissertação (Mestrado em História) - Universidade Federal de Goiás, Goiânia, 2015.

PINTO, General Francisco José. [Telegrama] 12/08/1937, Vitória [para] João Punaro Blay. Trata de orientações relacionadas às comemorações cívicas da semana da Pátria. Vitória, 1937. 
POMBO, José Francisco da Rocha. Nossa Pátria: Narração dos factos da História do Brasil, através da sua evolução com muitas gravuras explicativas. 34. ed. São Paulo, Companhia Melhoramentos de São Paulo, 1925.

POMBO, José Francisco da Rocha. História do Brasil. Nova edição Ilustrada. Rio de Janeiro São Paulo - Porto Alegre: W.M Jackson Inc. Editores, 1942, vol. I.

SCHMIDT, Maria Auxiliadora Moreira dos Santos. História do ensino de história no Brasil: uma proposta de periodização. Revista História da Educação - RHE, Porto Alegre, v. 16, n. 37, maio/ago, 2012, p. 73-91.

SCHWARCZ, Lília M., STARLING, Heloisa. Brasil: uma biografia. São Paulo: Companhia das Letras, 2015.

SIMÕES, Regina Helena Silva; SALIM, Maria Alayde Alcântara; TAVARES, Johelder Xavier. O Ginásio do Espírito Santo no contexto das políticas educacionais do Estado brasileiro (1933-1957). In: CONGRESSO LUSO-BRASILEIRO DE HISTÓRIA DA EDUCAÇÃO, 6., 2006, Uberlândia. Anais... Uberlândia: UFU, 2006.

TELMA. Ensino de História durante a Ditadura Militar no Espírito Santo. 2014. Entrevista concedida para elaboração de tese de doutorado desenvolvida no Programa de Pós-Graduação em Educação da Universidade Federal do Espírito Santo, Vitória, 2014.

TORRES, Lillian Cristina Cruvinel. Civismo e formação do cidadão em propostas curriculares na história recente do Brasil. In. VII Encontro Nacional Perspectivas do Ensino de História, 2012, Campinas. Anais... Campinas: Unicamp, 2012.

VARGAS, Getúlio. A criança, a maior vítima do comunismo. Diário da Manhã, Vitória, 10 dez. 1937.

VERA. Ensino de História durante a Ditadura Militar no Espírito Santo. 2014. Entrevista concedida para elaboração de tese de doutorado desenvolvida no Programa de Pós-Graduação em Educação da Universidade Federal do Espírito Santo, Vitória, 2014.

Submetido: $12 / 07 / 2019$

Aprovado: $20 / 02 / 2020$ 